\title{
STOCK MARKET COINTEGRATION AND DIVERSIFICATION OPPORTUNITIES UNDER INFLATION TARGETING REGIME
}

\author{
Albina Hysaj ${ }^{1 i}$, \\ Güven Sevil ${ }^{2}$ \\ ${ }^{1}$ Metropolitan University of Tirana, \\ Albania \\ ${ }^{2}$ Anadolu University, \\ Turkey
}

\begin{abstract}
:
Monetary authorities use monetary policy to achieve their objectives. Keeping inflation stable, at low levels is the main objective of central banks. While central banks use monetary policy to control inflation, its decisions also impact the overall economy and financial market. The aim of this paper is to investigate the diversification opportunities in 17 developed and emerging market economies that have implemented inflation targeting. By using Johansson cointegration and Gregory Hanssen tests we investigate the existence of long run co integration relationship between different markets. Moreover, we investigate the short run diversification opportunities by analyzing the short run exposure of each stock index to the S\&P 1200 Global Index. The results of our study suggest that stock markets of Brazil and Czech Republic offer very good diversification opportunities, while the Colombian stock market offers very limited diversification opportunities as Colombia stock index has co integration relationship with almost other indices.
\end{abstract}

JEL: G15, G11

Keywords: cointegration, diversification, stock markets, index

\section{Introduction}

Starting from 1990s, most of the countries in the world started following a liberal policy regarding financial markets, increasing the capital flows between countries. Following such a policy made the markets of each country easily accessible by the investors worldwide increasing the integration of financial markets. According to Sugisaki (1998), some of the factors that have contributed to the integration of financial markets are: technologic change; deregulation of financial markets; growth of institutional investors;

i Correspondence: email albinahysaj@gmail.com 
privatization of state assets; structural reforms in developing countries; financial innovation and financial cooperation.

High level of cointegration and correlation among markets is followed by reduced beneficiary from diversification. In this paper, we aim to investigate diversification opportunities between stock markets of emerging markets economies, that have high inflation and stock returns of all other countries under study. To investigate the cointegration relationship and diversification opportunities between markets we use Johansson cointegration test. We apply Gregory and Hansen cointegration test which is developed to test cointegration in the presence of structural shifts, in order to study the cointegration between markets in the presence of structural break. At the end we proceed with a simple version of CAPM model to investigate short run diversification opportunities.

There are many studies that investigate the relationship between financial markets of different countries however we are mostly concern about the relationship among emerging markets and developed market economies that have implemented inflation targeting regime. In their article Wong, et al. (2004) study the relationship between stock markets in developed countries and stock markets of Asian developing countries. They use weekly data from stock indices of United States, United Kingdom, Japan, Malaysia, Thailand, Korea, Taiwan, Singapore and Hong Kong, from January, 1981 to December, 2002 by dividing in three shorter periods. The authors conclude that the relationship between stock markets of developed countries with these in developing countries change over time. They observe an increased interdependence after the 1987 stock market crash. This interdependence is intensified even more after the 1997 Asian Financial Crisis, reducing the diversification opportunities. On the other hand, Auzairy et al. (2012) study the stock market integration among four countries; Malaysia, Thailand, Indonesia and South Korea from January 1997 to December 2009. By analyzing short run and long run market integration between those countries the authors find that there is not long run integration among those markets however there is short run cointegration.

Palamalai, Kalaivani, \& Devakumar (2013) investigate the stock market co integration among biggest markets of Asia Pacific economies as: India, Malaysia, Hong Kong, Singapore, South Korea, Taiwan, Japan, China and Indonesia. The authors identify a long run equilibrium relationship among these markets which means that long term diversification benefits on those markets is limited, however short run benefits may exist. Liu (2009) analyses the changes of stock markets interdependences in Asia Pacific countries over the period of 1993-2008. The author finds that since 1993 Asia Pacific countries have become increasingly integrated. Author identifies two important facts; first, aside from indices moving in the same direction, returns in those markets have become very similar as well; second, a big percentage of countries are more exposed to region risk and less to country specific risk.

Ergun \& Nor (2010) investigate the dynamic relationship and volatility spillover between stock market in Turkey and United States over the period 1988 to 2008. The results of the study indicate that there have been strong linkages between Istanbul Stock 
Exchange and NASDAQ stock market especially after Turkey signed Custom Union Agreement with European Union. Also, authors conclude that are observed significant volatility spillovers from NASDAQ to Istanbul stock exchange during this period.

Assidenou (2011) studies the co integration among Major Stock market indices during the 2008 Global Financial Distress with special focus over the period September, 2008 to August, 2009. Markets included in this research are categorized in three main groups: OECD group, Pacific group and Asia group. The author concludes that while in the beginning of 1990s the economic integration was more visible between USA and European countries now this integration is global and the Financial Crisis of 2008 effects were contagious in other countries as well. Lim (2007) examines the long-term integration among ASEAN -5 stock markets over the period April 1990 to August 2007. The study concludes that in the period after crisis there is an increased integration among ASEAN5 markets. Also, there is an increased integration between US markets and ASEAN-5 markets in the post crisis period and the returns in ASEAN-5 markets have been significantly influenced by US market returns.

Abidin, Reddy, \& Zhang (2015) investigate the intensity of price and volatility spillover in the five major stock markets in the Asia Pacific countries with a particular focus in the spillover effect between Australia and China. All the tests employed in this investigation show that there is an important spillover effect among Asia Pacific countries and also between Australia and China. While Çelik \& Baydan (2015) investigate the co movement of stock markets indices among countries such as USA, Turkey, Russia, China, India, Indonesia, Brazil and South Africa. The analysis shows that the co movement of China, India, Indonesia Turkey and USA are stronger than the co movements between other countries.

Chow, Huang, \& Niu (2011) study the economic integration of East Asian economies with each other and with US using the co movement of stock market prices. They find an increasing dependence among East Asian stock market but not so close relationship between Japan and US stock market, while they find an increasing linkage between China's and US stock markets.

\section{Empirical Methodology}

\subsection{Long-run Cointegration}

As we are using time series to study the cointegration relationship among stock markets it is necessary to ensure that data we are using are stationary. In order to check the stationarity, we use Augmented Dickey-Fuller unit root tests. The formulation of Augmented Dickey-Fuller model is given in equation (2.1).

$$
\Delta y_{t}=\theta y_{t-1}+\sum_{t=1}^{p} \theta_{i} \Delta y_{t-i}+u_{i t}
$$


The null hypothesis of the ADF test is $H_{0}: \theta=0$, meaning that there is a unit root, and series are not stationary, otherwise the alternative hypothesis $H_{a}: \theta<0$, that states that there is not a unit root and series are stationary.

To test for cointegration among stock indices we use VAR-based cointegration tests such as Johansen Test 1988. The long-run cointegration relationship between stock indices is described by the equation below that represents a VAR of order $\mathrm{p}$ :

$$
y_{t}=\alpha_{1} y_{t-1}+\ldots .+\alpha_{n} y_{t-p}+\beta x_{t}+u_{t}
$$

The bivariate long-run relationship between stock indices is:

$$
y_{t}=\alpha_{1} y_{t-1}+\beta x_{t}+u_{t}
$$

Where, yt is the log value of the stock price of Turkey, Czech Republic, Brazil, Mexico, Colombia and xt is the log of stock price of i-th country (Canada, Chile, Hungary, Iceland, Israel, Norway, Poland, South Africa, South Korea, Sweden, Thailand, UK)

We use (SC) Schwarz Information Criterion under VAR to determine lags. Johansen (1991) determines Trace and Maximum Eigenvalue tests (shown in equation $x$ and y) to investigate the existence of cointegration between stock markets. Numerous studies investigate and compare Trace and Maximum Eigenvalue Criteria. Lutkepohl, Saikkonen, \& Trenkler (2001) argue that the local power of maximum Eigenvalue and Trace criteria is very similar but may have some differences in a small sample. The authors conclude that Trace test tend to have more distorted sizes but in some situations this test is superior compared to maximum eigenvalue test. The Trace test tests the null hypothesis that the number of co integrating vectors is less than or equal to $r$, against the alternative that there is more than $\mathrm{r}$. The maximum Eigenvalue test conducts separate tests on the individual eigenvalues, where the null hypothesis is that the number of co integrating vectors is $r$, against an alternative of $(r+1)$.

$$
\begin{aligned}
& \lambda_{\text {Trace }}(r)=-T \sum_{i=r+1}^{g} \operatorname{in}\left(1-\lambda_{i}\right) \\
& \lambda_{\text {Max }}(r, r+1)=-T \ln \left(1-\lambda_{r+1}\right)
\end{aligned}
$$

Where,

$\mathrm{r}=$ number of co integrating vectors under the null

$\lambda_{\mathrm{i}}=$ estimated $\mathrm{i}$-th ordered eigenvalue

Johansen cointegration test has limited use in the presence of structural change when cointegration relationship has changed over time. In order to model time series in the presence of structural breaks, Gregory \& Hansen (1996) have developed residualbased tests for cointegration in models with regime shifts. They have designed three tests $\mathrm{ADF}, \mathrm{Z} \alpha$-, and $\mathrm{Zt}$ to test the null hypothesis of no cointegration against the alternative of 
existence of cointegration in the presence of single unknown timing structural break. Their test is developed for cases which are level shift, level shift with trend, and intercept with slope shifts. The models with their assumptions and two variables can be shown as below:

Model 1: Level Shift (C)

$$
Y_{t}=\mu_{1}+\mu_{2} q_{t k}+\alpha_{1} X_{1}+e_{t}
$$

Model 2: Level Shift with Trend (C/T)

$$
Y_{t}=\mu_{1}+\mu_{2} q_{t k}+\beta_{1} t+\alpha_{1} X_{t}+e_{1}
$$

Model 3: Regime Shift where Intercept and Slope coefficients change (C/S)

$$
Y_{t}=\mu_{1}+\mu_{2} q_{t k}+\beta_{1} t+\alpha_{1} X_{t}+\alpha_{2} X_{t} q_{t k}+e_{t}
$$

Where, $\mu_{1}, \alpha_{1}, \beta_{1}$ denote intercept, slope coefficients and trend coefficients before shift and $\mu_{2}, \alpha_{2}$, denote the corresponding changes after the shift.

\subsection{Short-run cointegration}

After testing long-run cointegration we also want to test for short-run diversification opportunities. To investigate short-run diversification opportunities we use sensitivity analysis based on Capital Asset Pricing model. This analysis is also previously used by Antiri \& Quansah (2017), Khan (2011). We use daily data of stock index for each country and daily data of the global index S\&P Global 1200"ii, for the period Jan 1 ${ }^{\text {st }}, 2002$ until Dec $31^{\text {st }}, 2017$. In order to obtain sensitivity analysis we use log price of each index. The model for each stock index is:

$$
r_{i}=\alpha+\beta r_{g}+\varepsilon_{i}
$$

Where, $r_{i}$ is the rate of return for each country index, $r_{g}$ is the rate of return for the global index, $\beta$ is the exposure of each country index to the global index. It shows how much sensitive is every country index from the movements of global index. After determining $\beta$ value for each country we will rank them based on its value.

\footnotetext{
ii S\&P Global 1200 is a composition of seven stock indices from 29 countries, used as a benchmark for global equity markets.
} 


\section{Empirical results}

\subsection{Long run diversification opportunities}

We use daily stock index data of Bovespa (BVSP), S\&P TSX Canada, S\&P CLX IPSA Chile, FTSE Colombia, FTSE Czech Republic, FTSE Hungary, ICEX Main Iceland, TA 125, S\&P BMV IPC, OSE Benchmark, FTSE JSE, KOSPI, OMX Stockholm, SET Index, FTSE 100, BIST 100, WIG30. The data consist of the daily prices of the indices form January $1^{\text {st }} 2001$ to December $31^{\text {st }} 2017$. There are a total of 4174 observations for each index. The log values of all series are shown in Figure 3.1.

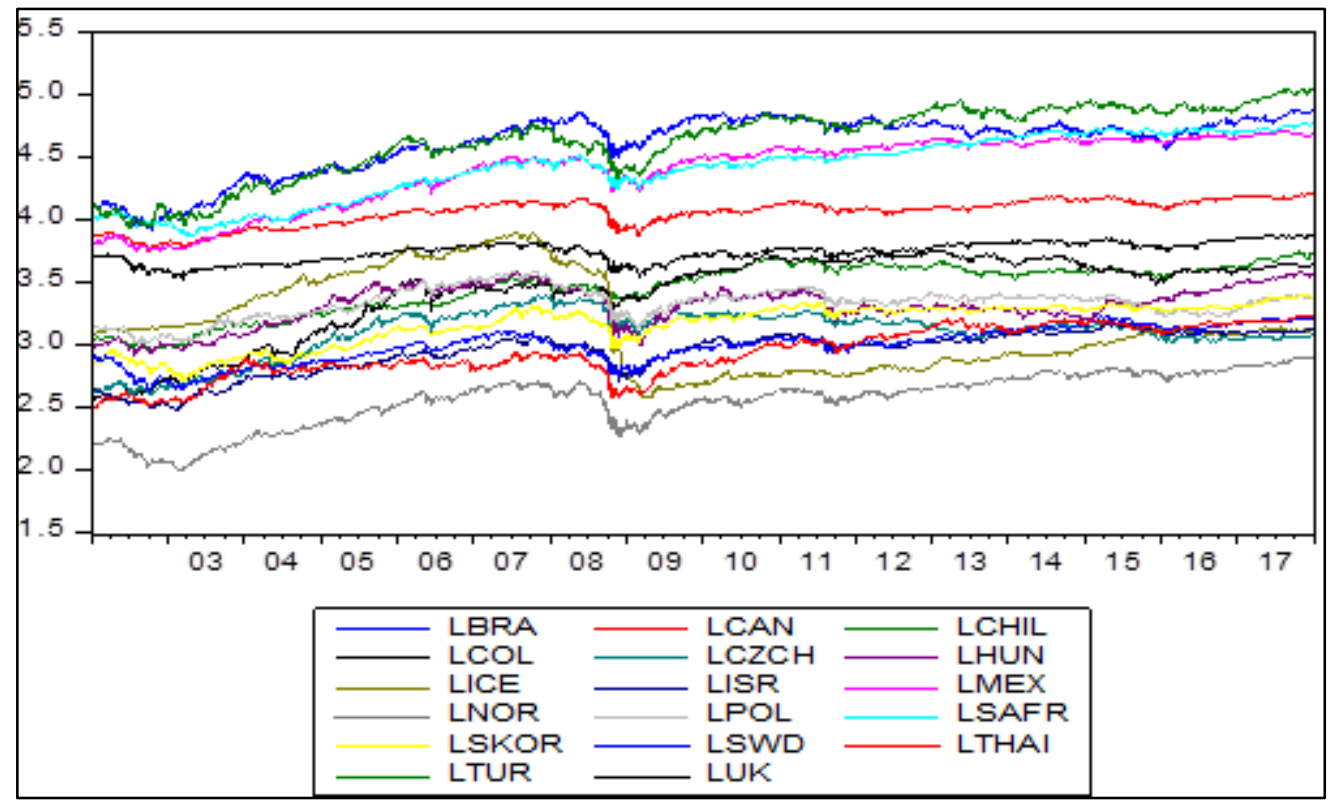

Figure 3.1: Log value of stock indices

We conduct Augmented Dickey-Fuller to test if the series are stationary or not. Johannsen cointegration test holds under the assumption that time series have the same order of cointegration, different from level. Null hypothesis supposes that series are not stationary, while we need stationary series to proceed with cointegration test.

- Null hypothesis: There is a unit root

- Alternative Hypothesis: There is not a unit root.

For level series we can not reject the null hypothesis as probability is higher than $\% 5$, but for first difference we reject null hypothesis meaning that series are stationary at the first difference. Table 3.1 shows the results of unit root test.

As the series are stationary at first difference, we can proceed with the estimation of Johansson Cointegration Test. The results of bivariate Johansson Cointegration Test are shown in the appendix. 


\begin{tabular}{|c|c|c|c|c|}
\hline \multicolumn{5}{|c|}{ Table 3.1: Unit Root Test - Stock return } \\
\hline & \multirow{2}{*}{$\begin{array}{r}\text { Unit root test stationary at level } \\
\text { Augmented } \\
\text { Dickey-Fuller }\end{array}$} & \multicolumn{2}{|c|}{ Stationary at $1^{\text {st }}$} & \multirow{2}{*}{$\begin{array}{l}\text { Difference } \\
\text { inted } \\
\text { Fuller }\end{array}$} \\
\hline & & & & \\
\hline Country & t-statistic & Probability & t-statistic & Probability \\
\hline Brazil & -1.747435 & 0.7299 & -65.26640 & 0.0000 \\
\hline Canada & -2.046419 & 0.5750 & -29.11125 & 0.0000 \\
\hline Chile & -1.694553 & 0.7538 & -55.38536 & 0.0000 \\
\hline Colombia & -1.733034 & 0.7365 & -57.71191 & 0.0000 \\
\hline Czech & -1.777036 & 0.7159 & -47.70662 & 0.0000 \\
\hline Hungary & -1.949341 & 0.6281 & -31.07189 & 0.0000 \\
\hline Iceland & -1.116931 & 0.9248 & -63.73442 & 0.0000 \\
\hline Israel & -1.718423 & 0.7432 & -62.21386 & 0.0000 \\
\hline Mexico & -1.533674 & 0.8181 & -59.88015 & 0.0000 \\
\hline Norway & -1.930819 & 0.6380 & -65.07760 & 0.0000 \\
\hline Poland & -2.080356 & 0.5561 & -46.75631 & 0.0000 \\
\hline South Africa & -2.058540 & 0.5683 & -62.81920 & 0.0000 \\
\hline South Korea & -2.392807 & 0.3832 & -63.53473 & 0.0000 \\
\hline Sweden & -3.089660 & 0.1088 & -66.65367 & 0.0000 \\
\hline Thailand & -2.632946 & 0.3622 & -43.10820 & 0.0000 \\
\hline Turkey & -2.132737 & 0.5267 & -64.09036 & 0.0000 \\
\hline UK & -2.915567 & 0.1575 & -31.50465 & 0.0000 \\
\hline
\end{tabular}

\subsubsection{Johansson cointegration results}

\section{A. BIST - Other indices}

Trace test indicates there are two cointegration equation between stock market of Turkey and stock market of Colombia, While Maximum Eigenvalue criteria indicates there is not any cointegration equation among those indices. Both Trace and Eigenvalue confirm co integration between stock index of Turkey and stock index of Israel, South Korea, Canada, UK, South Africa, Sweden and Mexico, while there is not cointegration relationship between BIST and stock indices of Chile, Hungary, Thailand, Iceland, Poland, Norway, Brazil, Colombia, and Czech Republic.

\section{B. BOVESPA - Other indices}

Trace test indicates there are two cointegration equation between stock market of Brazil and stock market of Colombia, while there is not bivariate long run cointegration relationship between stock prices of Brazil and stock indices of other countries.

\section{FTSE Colombia - Other indices}

Cointegration test shows that there is long-run bivariate cointegration relationship among stock index of Colombia and stock indices of Sweden, South Africa, and UK. As mentioned earlier we have used Johansen cointegration with two criteria Trace and Maximum Eigenvalue criteria. Trace criteria indicates there are two cointegration equations, among stock index of Colombia, and stock indices of Turkey, Brazil, Canada, 
Chile, Israel, Mexico, Norway, South Korea, Poland, while according to Maximum Eigenvalue criteria there is not any cointegration equation among those indices. There is not long-run bivariate relationship between stock index of Colombia and stock index of Hungary, Thailand, Iceland, Czech Republic.

\section{FTSE Czech Republic - Other indices}

Cointegration test shows there is no bivariate long run cointegration relationship between relationship stock index of the Czech Republic and other indices.

\section{E. S\&P BMV ICP Mexico - Other indices}

Trace test indicates there are two cointegration equation between stock market of Mexico and stock market of UK, South Africa, Colombia and one cointegration equation between stock market of Mexico and stock market of Israel, while Maximum Eigenvalue criteria indicates there is not any cointegration equation among those indices. Both Trace and Eigenvalue confirm cointegration between stock index of Mexico and stock index of South Korea, Sweden, Poland, Turkey, while there is no bivariate long run cointegration relationship between stock index of Mexico and stock index of Canada, Chile, Hungary, Thailand, Iceland, Norway, Brazil, and Czech Republic.

Table 3.2: Johansson cointegration results

\begin{tabular}{|c|c|c|c|c|c|}
\hline \multirow[t]{2}{*}{ All Countries } & \multicolumn{5}{|c|}{ Emerging Markets that Have Deviation } \\
\hline & Turkey & Brazil & Colombia & Czech Rep & Mexico \\
\hline Iceland & - & - & - & - & - \\
\hline Sweden & Coint & - & Coint & - & Coint \\
\hline Poland & - & - & Trace & - & Coint \\
\hline Norway & - & - & Trace & - & - \\
\hline Israel & Coint & - & Trace & - & Trace \\
\hline South Korea & Coint & - & Trace & - & Coint \\
\hline Canada & Coint & - & Trace & - & - \\
\hline UK & Coint & - & Coint & - & Trace \\
\hline South Africa & Coint & - & Coint & - & Trace \\
\hline Chile & - & - & Trace & - & - \\
\hline Hungary & - & - & - & - & - \\
\hline Thailand & - & - & - & - & - \\
\hline Turkey & l & - & Trace & - & Coint \\
\hline Brazil & - & I & Trace & - & - \\
\hline Colombia & Trace & Trace & I & - & Trace \\
\hline Czech Rep & - & - & - & 1 & - \\
\hline Mexico & Coint & - & Trace & - & I \\
\hline
\end{tabular}

The results of Johansson Co integration test indicate that investors from Czech Republic can take long-run diversification benefits by investing in all countries, while investors from Brazil can have long run diversification benefits in all countries apart from Colombia. Investors from Colombia can benefit from long-run diversification by investing in countries such as Iceland, Hungary, Thailand, and Czech Republic. Investors 
from Turkey can have long-run diversification benefits by investing in Iceland, Poland, Norway, Chile, Hungary, Thailand, Brazil, and Czech Republic. Investors from Mexico may benefit from long-rung diversification opportunities by investing in countries such as Iceland, Norway, Canada, Chile, Hungary, Thailand, Brazil, and Czech Republic.

\subsubsection{Gregory and Hansen test results}

After Johansson cointegration we proceed with the results of Gregory and Hansen test which take into consideration a structural shift in the time series. Gregory and Hansen's test indicates there is long-run relationship between stock market of emerging market economies that have deviation from target and markets of developed countries that do not have deviation from inflation target. The only markets that are not co integrated are stock market of Colombia and stock market of South Korea. Cointegration analysis between stock markets of emerging markets economies that have deviation from target and developed countries that also have deviation from target shows that there is bivariate long-run relationship among most of markets of those two groups. The bivariate longrun relationship is not detected only between stock market of Brazil and Norway, and between stock market of Czech Republic and Poland.

The cointegration analysis between stock markets of emerging market economies that have deviation from the target and emerging market economies that do not have deviation from market shows that there is not bivariate long-run relationship between stock markets of South Africa and Thailand with markets of our focus group. The only market that behaves differently from group is stock market of Mexico which has a bivariate long-run relationship with stock market of South Africa and Thailand while does not have long-run co movement with stock markets of Chile and Hungary. The cointegration test for stock markets of emerging market economies among each other shows that there is bivariate long-run relationship between stock markets of this group. The only market that behaves differently is Colombia which does not have long-run relationship with stock markets of Brazil and Mexico. Table 5.3 shows the summarized results of Gregory Hansen test. The test indicates that the long-run diversification benefits are very low.

Our results are the same as Öztürk (2018) who studies the cointegration relationship between BIST 30 and MSCI emerging market index which consists of the indices from 24 emerging countries, from January 2003 to July 2017. The author finds there is a significant long-term relationship between BIST and MSCI index. Also, Geyikci (2017), who studies the diversification opportunities among stock market of Turkey and stock markets of 12 other countries including Brazil, Poland, Hungary, Czech Republic, Thailand, and South Korea concludes that there is long run relationship between those markets. In accordance with our results are Coleman, Leon, \& Medeiros (2018), who investigate the co movement and dynamics between Latin American markets such as stock markets of Mexico, Brazil, Chile, Peru, Argentina, and Venezuela. The authors find evidence of co movement among those markets, especially between Mexico and all other stock markets. 
Table 3.3: Gregory and Hansen test results

\begin{tabular}{|l|c|c|c|c|c|}
\hline \multirow{2}{*}{ All Countries } & \multicolumn{5}{|c|}{ Emerging markets that have deviation } \\
\hline & Turkey & Brazil & Colombia & Czech Rep & Mexico \\
\hline Iceland & Coint & Coint & Coint & Coint & Coint \\
\hline Sweden & Coint & Coint & Coint & Coint & Coint \\
\hline Poland & Coint & Coint & Coint & - & Coint \\
\hline Norway & Coint & - & Coint & Coint & Coint \\
\hline Israel & Coint & Coint & Coint & Coint & Coint \\
\hline South Korea & Coint & Coint & - & Coint & Coint \\
\hline Canada & Coint & Coint & Coint & Coint & Coint \\
\hline UK & Coint & Coint & Coint & Coint & Coint \\
\hline South Africa & - & - & - & - & Coint \\
\hline Chile & Coint & Coint & Coint & Coint & - \\
\hline Hungary & Coint & Coint & Coint & Coint & - \\
\hline Thailand & - & - & - & - & Coint \\
\hline Turkey & $/$ & Coint & Coint & Coint & Coint \\
\hline Brazil & Coint & $/$ & - & Coint & Coint \\
\hline Colombia & Coint & Coint & $/$ & Coint & Coint \\
\hline Czech Rep & Coint & Coint & Coint & $/$ & Coint \\
\hline Mexico & Coint & Coint & - & Coint & $/$ \\
\hline
\end{tabular}

\subsection{Short-run diversification opportunities}

In the last part of this section, we aim to investigate the short-run diversification opportunities by analyzing the exposure of every stock index to S\&P 1200 Global index. By using equation (2.9) $)^{\mathrm{iii}}$ we determine $\beta$ value for each stock index which represents the sensitiveness of each index to the global index. Values of $\beta$ are shown in Table 5.4.

Table 5.4: Value of Beta

\begin{tabular}{|l|c|c|}
\hline Country & Beta & Probability \\
\hline Brazil & ${ }^{*} 0.087269$ & 0.001 \\
\hline Canada & ${ }^{*} 0.102159$ & 0.000 \\
\hline Chile & ${ }^{*} 0.125798$ & 0.000 \\
\hline Colombia & $0.393512^{*}$ & 0.000 \\
\hline Czech Rep & $0.559462^{*}$ & 0.000 \\
\hline Hungary & $0.797150^{*}$ & 0.000 \\
\hline Iceland & ${ }^{*} 0.131162$ & 0.000 \\
\hline Israel & ${ }^{*} 0.177191$ & 0.000 \\
\hline Mexico & ${ }^{*} 0.074977$ & 0.000 \\
\hline Norway & 0.289869 & 0.000 \\
\hline Poland & 0.238037 & 0.000 \\
\hline S. Africa & 0.297464 & 0.000 \\
\hline S. Korea & $0.46743^{*}$ & 0.000 \\
\hline Sweden & 0.211982 & 0.000 \\
\hline Thailand & 0.299849 & 0.000 \\
\hline Turkey & 0.255882 & 0.000 \\
\hline UK & ${ }^{*} 0.18915$ & 0.000 \\
\hline
\end{tabular}

\section{iii Page 4}


The p-value for all coefficients is lower than $5 \%$ meaning that all the coefficients are significant. Betas values show that stock markets of countries such as Hungary, Czech Republic, South Korea, and Colombia have relatively high exposure to the global index. Countries such as Mexico, Brazil, Canada, Chile, Iceland, Israel, and UK have very low exposure to the global index. Countries that have a low expose to global market offer very good short term diversification opportunities.

\section{Conclusion}

In this article we investigate the diversification opportunities between 17 developed and emerging market economies that have implemented inflation targeting regime. We use Johansen Cointegration and Gregory \& Hansen for structural change, to analyze whether there is long run cointegration among stock markets. Johansen cointegration test suggests that Brazil and Czech Republic markets are very good diversification opportunities, as the Brazilian and Czech index are not co integrated with almost all other indices. On the other side the Colombian stock index has cointegration relationship with almost other indices. By investigating the exposure of every country index to a global index we find that in short run investors may benefit by investing in stock markets of Mexico, Brazil, Canada, Chile, Iceland, Israel, and UK.

The findings of our study are particularly important in the area of high capital flows among markets, high frequency trading, and increased access of the investors in the worldwide financial markets. Our study implicates that investors may benefit by including in their portfolio stock markets of countries such as Czech Republic and Brazil even though these countries have continuously high inflation. Stock markets of Turkey and Mexico offer limited diversification opportunities, whether stock market of Colombia is cointegrated with most of other markets, meaning that investors should be cautious while considering to include stock market of Colombia in their portfolios.

A further extension of this study might be the investigation of the factors which contribute to the linkage and the relationship between stock markets and the analysis of whether the economic cointegration and regional agreement affect the level of cointegration among stock markets.

\section{Conflict of Interest Statement}

The authors hereby declare that they have no affiliations with or involvement in any organization/entity with any financial or non-financial interest in the subject or materials discussed in this manuscript.

\section{About the Authors}

Prof. Dr. Güven Sevil is a full time professor at Open Education Faculty, Anadolu University. Prof. Sevil is specialized in subjects such as Risk Management and Insurance, Financial Economics and Behavioral Economics, Financial Markets and Institutions, Investment and Portfolio Management, and so forth. He is the author and coauthor of 
several articles published in high impact journals and the author of 17 books. His research interest is related with areas in which he is specialized.

Dr. Albina Hysaj is a full time lecturer at Faculty of Economy, Metropolitan University of Tirana. She has a PhD in Finance. She teaches subjects such as Finance Foundations, Corporate Finance and Financial Industry. Her research interest is focused in areas such as Financial Markets, Financial Economics and so forth.

\section{Bibliography}

Abidin, S., Reddy, K., \& Zhang, C. (2015). Intensity of Price and Volatility Spillovers Effects in Asia Pacific Basin Equity Markets. Australasian Accounting Business and Finance Journal, 3-18.

Andrew, B. (2012, November). The national bureau of economic research. Retrieved May 2016, from the national bureau of economic research: http://www.nber.org/digest/jan99/w6724.html

Antiri, G. A., \& Quansah, E. (2017). Cointegration of Stock Prices and Domestic Portfolio Diversification Opportunities: Evidence from the Ghana Stock Exchange. Applied Economics and Finance, 4(5), 78-93. doi: https://doi.org/10.11114/aef.v4i5.2475

Assidenou, K. E. (2011). Cointegration of Major Stock Market Indices during the 2008 Global Financial Distress. International Journal of Economics and Finance, 212-222.

Auzairy, N. A., Ahmad, R., Ho, C. S., \& Sapian, R. Z. (2012). Integration of Asian Stock Markets. International Journal of Social, Behavioral, Educational, Economic, Business and Industrial Engineering, 3503-3509.

Coleman, S., Leon, V., \& Medeiros, O. R. (2018). Latin American stock market dynamics and comovement. International Journal of Finance $\mathcal{E}$ Economics, 24, 1109-1129. DOI: 10.1002/ijfe.1708

Çelik, S., \& Baydan, E. (2015, May). Bringing a new perspective on Co movements of stock markets in emerging economies through causality and wavelet analysis. Topics in Middle Eastern and African Economies, pp. 26-51.

Chow, G. C., Huang, S., \& Niu, L. (2011). Princeton University. Retrieved May 2016, from Princeton

University: https://www.princeton.edu/ gchow/Econometric\%20Analysis\%20of\%20Stock $\% 2$ 0Price\%2020111004.pdf

Ergun, U., \& Nor, A. H. (2010). The stock market relationship between Tukey and the United States under unionisation. Asian Academy of Management Journal of Accounting and Finance, 19-33.

Geyikci, U. B. (2017). Test for cointegration and causality between ISE and emerging market indices; diversification opportunities for investors. International Journal of Human Sciences, 14(4), 3486-3503. DOI:10.14687/jhs.v14i4.4943

Gregory, A. w., \& Hansen, B. E. (1996). Residual-Based tests for cointegration in models with regime shifts. Journal of Econometrics(70), 99-126. Retrieved from 
https://reader.elsevier.com/reader/sd/pii/0304407669416857?token=1DE4D0C89F 7C19CDC1C6D2D7724AE53249A11459460AF546A23DF76DCF0986A9E0BC1F66 FC02B136C2A5A742B9ACFF60

Johansen, S. (1991, November). Estimation and Hypothesis Testing of Cointegration Vectors in Gaussian Vector Autoregressive Models. Econometrica, 59(6), 1551-1580.

Khan, T. A. (2011). Cointegration of International Stock Markets: An Investigation of Diversification Opportunities. Undergraduate Economic Review, 8(1). Retrieved from https://core.ac.uk/download/pdf/59225272.pdf

Lim, L. K. (2007). Modelling and Simulation Society of Australia and New Zealand Inc. (MSSANZ). Retrieved May 2016, from Modelling and Simulation Society of Australia and New Zealand Inc. (MSSANZ): http://www.mssanz.org.au/MODSIM07/papers/29_s1/LinkagesBetween_s1_Lim_ .pdf

Liu, C. (2009, May). Regional Integration of Stock Markets in Asia Pacific Countries.

Gregory, H., Saikkonen, P., \& Trenkler, C. (2001). Maximum eigenvalue versus trace tests for the cointegrating rank of a VAR process. Econometrics Journal, 4, 287-310.

Öztürk, H. (2018). Cointegration Analysis of BIST 30 Index and MSCI Emerging Markets Index: Pre and Post Global Financial Crisis. Business and Economics Research Journal, 9(1), 109-121. DOI:: 10.20409/berj.2017.89

Palamalai, S., Kalaivani, M., \& Devakumar, C. (2013). Stock Market Linkages in Emerging Asia- Pacific Markets. Sage Publications, 1-15.

Sugisaki, S. (1998, December 5). International Monetary Fund. Retrieved May 2, 2016, from International Monetary Fund: https://www.imf.org/external/np/speeches/1998/120598.htm

Wong, W.-K., Penm, J., Terrel, R. D., \& Lim, Y. C. (2004). The relationship between stock markets of major developed countries and Asian emerging markets. Journal of Applied Mathematics and Decision Sciences, 201-218.

Yang, J., Kolari, J. W., \& Min, I. (2003). Stock market integration and financial crises: the case of Asia. Applied Financial Economics, 477-486. 

distribute, transmit or adapt the article content, providing a proper, prominent and unambiguous attribution to the authors in a manner that makes clear that the materials are being reused under permission of a Creative Commons License. Views, opinions and conclusions expressed in this research article are views, opinions and conclusions of the author(s). Open Access Publishing Group and European Journal of Economic and Financial Research shall not be responsible or answerable for any loss, damage or liability caused in relation to/arising out of conflict of interests, copyright violations and inappropriate or inaccurate use of any kind content related or integrated on the research work. All the published works are meeting the Open Access Publishing requirements and can be freely accessed, shared, modified, distributed and used in educational, commercial and non-commercial purposes under a Creative Commons Attribution 4.0 International License (CC BY 4.0). 